\title{
Effect of Potassium and Sulphur on Yield Attributes, Yield and Quality of Summer Groundnut (Arachis hypogaea L.) under Middle Gujarat Condition
}

\author{
P.K. Patel*, M.B. Viradiya, V.H. Kadivala and R.D. Shinde \\ Department of Soil Science \& Agril. Chemistry, B. A. College of Agriculture, Anand \\ Agricultural University, Anand - 388110 (Gujarat), India \\ *Corresponding author
}

\section{Key w ords \\ Potassium, Sulphur, Yield, Quality, Groundnut \\ Article Info \\ Accepted: \\ 16 August 2018 \\ Available Online: \\ 10 September 2018}

\section{A B S T R A C T}

A field experiment was conducted at the college Agronomy farm, Anand Agricultural University, Anand (Gujarat) during summer season of the year 2017 to study the role of potassium and sulphur on yield attributes, yield and quality of summer groundnut (Arachis hypogaea L.) under middle Gujarat conditions. The experimental soil was loamy sand in texture having $\mathrm{pH}$ of 7.80. The experiment included four levels of potassium viz. 0, 25, 50 and $75 \mathrm{~kg} \mathrm{~K}_{2} \mathrm{O} \mathrm{ha}^{-1}$ and three levels of sulphur viz. 0,20 and $40 \mathrm{~kg} \mathrm{~S} \mathrm{ha}^{-1}$. The experiment was laid out in a Randomized Block Design (Factorial) with four replications. Potassium showed significant effect on yield and yield attributes of groundnut. Application of potassium @ $75 \mathrm{~kg} \mathrm{~K}_{2} \mathrm{O} \mathrm{ha}{ }^{-1}$ produced significantly highest dry matter content at $45 \mathrm{DAS}$, no. of branches plant ${ }^{-1}$, no. of pod plant ${ }^{-1}$, shelling $\%$, seed index, pod yield, haulm yield and protein content. Sulphur fertilizer also gave significant effect on yield and yield attributes of groundnut. Application of sulphur @ $40 \mathrm{~kg} \mathrm{~S} \mathrm{ha}^{-1}$ produced the highest dry matter content at 45 DAS, no. of branches plant ${ }^{-1}$, no. of pod plant ${ }^{-1}$, shelling $\%$, seed index, pod yield, haulm yield, oil content and protein content. Potassium in combination with sulphur showed significant effect on yield and yield attributes of groundnut. Combined application of potassium @ $75 \mathrm{~kg} \mathrm{ha}^{-1}$ and sulphur @ $40 \mathrm{~kg} \mathrm{ha}^{-1}$ resulted significantly the highest no. of branches plant ${ }^{-1}$, no. of pod plant ${ }^{-1}$, pod yield, haulm yield and shelling \% of groundnut. On the other hand, in all the cases the lower response was found from the control treatment.

\section{Introduction}

Fertilizer played a vital role in increasing the productivity of crop even after green revolution. Though India occupies unique position in the area and production of oilseeds, judicious fertilizer management plays a pivotal role in influencing the crop yield significantly. Groundnut (Arachis hypogaea
L.) is known to be a unique and important legume cum oilseed crop of India accounting $33 \%$ of world's groundnut area and about $27.3 \%$ production. It belongs to Leguminoseae family. It is also known as peanut, monkey nut, earthnut, manila nut and goober. It is world's largest source of edible oil and ranks $13^{\text {th }}$ among the food crops as well as $4^{\text {th }}$ most important oilseed crops of the world. It is a 
leading oilseed crop in India with an area of 6.64 million hectares and production of 6.77 million tone of groundnut at an average productivity of $1020 \mathrm{~kg} \mathrm{ha}^{-1}$ during summer season (FAO STAT, 2007). It is a multipurpose crop contains $45 \%$ to $51 \%$ high quality hydrogenated edible oil and 26\% dietary proteins, $24.2 \%$ soluble carbohydrates and minerals. The kernels also rich in vitamin $\mathrm{E}, \mathrm{K}$ and all $\mathrm{B}$ vitamins except $\mathrm{B}_{12}$.

Potassium is one of the three major essential nutrient elements required by plants. Though potassium is not a constituent of any compound or structurally bound in groundnut, it is required for translocation of assimilates and involved in maintenance of water status of plant especially the turgor pressure of cells and opening and closing of stomata and increase the availability of metabolic energy for the synthesis of starch and proteins. Besides, it increased peg formation, nodulation, synthesis of sugar and starch and help in pod growth and filling.

Sulphur is the fourth major nutrient and plays an important role in the nutrition of oil-seed crop and as a constituent of sulphur containing amino acids cystine, cysteine and methionine (Gangadhara et al., 1990). In oil seed crops it is also involved in the formation of glucocides or glucosinolates which on hydrolysis increase the oil content. One of the main functions of sulphur in proteins or polypeptides is the formation of disulphide bonds between polypeptide chains. Disulphide linkages are important in stabilizing and determining the configuration of proteins. The application of sulphur increased the uptake of various macro and micro nutrients in groundnut (Singh, 1999).

\section{Materials and Methods}

A field experiment was conducted at the college Agronomy farm, Anand Agricultural
University, Anand (Gujarat) during summer season of the year 2017 to study the effect of potassium and sulphur in improving production of summer groundnut (Arachis hypogaea L.). The soil of experimental field was Typic Ustocrept (Inceptisol) which is loamy sand of alluvial origin having good drainage and moderate moisture retention. Soil $\mathrm{pH}$ was neutral to alkaline with poor organic matter and nitrogen, medium in available phosphorus and high in available potash content. It was deficient to moderate in sulphur, iron and zinc contents.

The experiment was laid out in a factorial randomized block design with 12 treatment combinations and replicated four times. It consist of four levels of potassium viz. 0, 25, 50 and $75 \mathrm{~kg} \mathrm{~K}_{2} \mathrm{O} \mathrm{ha}^{-1}$ applied as Muriate of potash and three levels of sulphur viz. 0, 20 and $40 \mathrm{~kg} \mathrm{~S} \mathrm{ha}^{-1}$ applied as Bentonite sulphur. The full dose of nitrogen $\left(25 \mathrm{~kg} \mathrm{ha}^{-1}\right)$ and of $\mathrm{P}_{2} \mathrm{O}_{5}\left(50 \mathrm{~kg} \mathrm{ha}^{-1}\right)$ were added through urea and DAP as basal application in each plot. The treatment wise sulphur and potassium were applied though bentonite sulphur and muriate of potash, respectively as basal. The crop was dibbled at $45 \mathrm{~cm}$ raw to raw spacing. The crop was raised with standard package of practices. The crop was harvested at maturity and plot wise yield attributes, haulm and pod yield were recorded. Oil content was determined by non-destructive method using Nuclear Magnetic Resonance as suggested by A.O.A.C., (1956) and Oil content was estimated by multiplied nitrogen content of respective components by a factor of 6.25 as suggested by Gupta et al., (1973).

\section{Results and Discussion}

\section{Effect of potassium on yield attributes}

Data presented in Table 1 revealed that application of $75 \quad \mathrm{~kg} \quad \mathrm{~K}_{2} \mathrm{O} \quad \mathrm{ha}^{-1}$ gave significantly higher $(4.50 \mathrm{~g})$ dry matter 
content at 45 DAS which remains at par with $50 \mathrm{~kg} \mathrm{~K}_{2} \mathrm{O}$ ha $^{-1}$. Significantly the highest number of branches plant ${ }^{-1}$ (7.17) was noted at $75 \mathrm{~kg} \mathrm{~K}_{2} \mathrm{O}$ ha $^{-1}$. Application of $75 \mathrm{~kg} \mathrm{~K}_{2} \mathrm{O}$ ha $^{-1}$ gave significantly higher (12.17) number of pods which remains at par with $50 \mathrm{~kg} \mathrm{~K}_{2} \mathrm{O}$ $\mathrm{ha}^{-1}$. Significantly higher shelling \% (74.24\%) and seed index $(45.08 \mathrm{~g})$ was found at $75 \mathrm{~kg}$ $\mathrm{K}_{2} \mathrm{O}$ ha $^{-1}$, which remains at par with $50 \mathrm{~kg}$ $\mathrm{K}_{2} \mathrm{O} \mathrm{ha}^{-1}$. Effect of different levels of potassium was found to be non-significant in case of plant population, plant height and harvest index. The increase in yield attributes of plant might be due to the potassium play a vital role in maintaining balance in enzymatic, stomatal activity, transport of sugar and synthesis of protein, photosynthesis and starch. Our findings are supported by Sahay et al., (2013).

\section{Effect of sulphur on yield attributes}

Yield attributing characters like dry matter content at 45 DAS, no. of branches plant ${ }^{-1}$, no. of pod plant ${ }^{-1}$, shelling $\%$, seed index (100 seed weight) of groundnut were increased significantly with increasing levels of sulphur, while the plant population, plant height and harvest index was found to be non-significant with different levels of sulphur (Table 1). The treatment $\mathrm{S}_{2} \quad\left(\begin{array}{llll}40 & \mathrm{~kg} & \mathrm{~S} & \mathrm{ha}^{-1}\end{array}\right)$ recorded significantly higher $(4.43 \mathrm{~g})$ dry matter accumulation per plant at 45 DAS and it was remains at par with treatment $S_{1}(20 \mathrm{~kg} \mathrm{~S}$ $\left.\mathrm{ha}^{-1}\right)$. Application $40 \mathrm{~kg} \mathrm{~S} \mathrm{ha}$ recorded significantly the highest number of branches plant $^{-1}$ (7.81). Treatment $\mathrm{S}_{2}\left(40 \mathrm{~kg} \mathrm{~S} \mathrm{ha}{ }^{-1}\right)$ recorded significantly higher number of pods plant $^{-1}$ (12.19), but it was at par with treatment $\mathrm{S}_{1}$ (11.81). Data showed that significantly the highest shelling percentage of $(73.80 \%)$ and seed index (41.02 g) was observed under the treatment $\mathrm{S}_{2}\left(40 \mathrm{~kg} \mathrm{~S} \mathrm{ha}^{-1}\right)$. Yield attributes were significantly increased at each increasing level of applied sulphur. This might be due to the fact that sulphur application improved over all nutritional environment of the Rhizosphere as well as plant system which could be more advantageous for profused vegetative and root growth which activated higher absorption of nutrients from the soil and improved metabolic activities inside the plant. Similar results were observed by Naiknaware et al., (2015).

Interaction effect of potassium and sulphur showed significant effect on yield attributes of groundnut. Combined application of potassium@75 kg ha ${ }^{-1}$ and sulphur@ $@ 40 \mathrm{~kg}$ $\mathrm{ha}^{-1}$ resulted the highest no. of branches plant $^{-1}$, no. of pod plant $^{-1}$ and shelling $\%$ of groundnut.

\section{Effect of potassium on yield}

The pod and haulm yields of groundnut were significantly influenced by graded levels of potassium (Table 2). The significantly higher pod yield $\left(2128 \mathrm{~kg} \mathrm{ha}^{-1}\right)$ of groundnut was recorded with application of $75 \mathrm{~kg} \mathrm{~K}_{2} \mathrm{O} \mathrm{ha}{ }^{-1}$, which was at par with $50 \mathrm{~kg} \mathrm{~K}_{2} \mathrm{O}$ ha $^{-1}$. Beneficial effect of potassium on grain production is related to its known role in plant nutrition, in many physiological and metabolic processes, including photosynthesis, osmoregulation, transport of nutrients, transport and storage of carbohydrates from which fat has formed, nitrogen absorption and synthesis of proteins and starch. Treatment receiving application of potassium @ $75 \mathrm{~kg}$ $\mathrm{ha}^{-1}\left(\mathrm{~K}_{3}\right)$ recorded significantly higher haulm yield (4404 $\mathrm{kg} \mathrm{ha}^{-1}$ ) which was at par with treatment $\mathrm{K}_{50}\left(4219 \mathrm{~kg} \mathrm{ha}^{-1}\right)$. Potassium helps in the resistance to crops against pests and diseases, which, in turn, increased the yield. Potassium also make a pronounced role in carbohydrates synthesis, photosynthesis cell elongation, stomatal activity and higher nutrient uptake under this level resulted in higher plant height and number of branches per plant and ultimately helped in realization of higher haulm yield. 
Table.1 Effect of levels of potassium and sulphur on yield attributes of summer groundnut

\begin{tabular}{|c|c|c|c|c|c|c|c|c|}
\hline Treatments & $\begin{array}{c}\text { Plant } \\
\text { population }\end{array}$ & $\begin{array}{c}\text { Dry } \\
\text { matter } \\
\text { content } \\
\text { at } 45 \\
\text { DAS }\end{array}$ & $\begin{array}{c}\text { No. of } \\
\text { branches } \\
\text { plant }^{-1}\end{array}$ & $\begin{array}{c}\text { No. of } \\
\text { pod } \\
\text { plant }^{-1}\end{array}$ & $\begin{array}{l}\text { Plant } \\
\text { height } \\
(\mathrm{cm})\end{array}$ & $\begin{array}{c}\text { Shelling } \\
\%\end{array}$ & $\begin{array}{c}\text { Seed } \\
\text { index } \\
(\mathrm{g})\end{array}$ & $\begin{array}{c}\text { Harvest } \\
\text { index } \\
(\%)\end{array}$ \\
\hline \multicolumn{9}{|c|}{ Level of potassium $\left(\mathrm{kg} \mathrm{ha}^{-1}\right)$} \\
\hline $\mathbf{K}_{\mathbf{0}}$ & 15.54 & 3.96 & 6.00 & 10.08 & 28.88 & 66.92 & 41.10 & 32.02 \\
\hline $\mathbf{K}_{1}$ & 15.88 & 4.19 & 6.50 & 11.25 & 29.58 & 68.95 & 42.34 & 31.58 \\
\hline $\mathrm{K}_{\mathbf{2}}$ & 16.29 & 4.30 & 6.75 & 11.75 & 30.21 & 71.90 & 43.18 & 32.49 \\
\hline $\mathbf{K}_{3}$ & 16.63 & 4.50 & 7.17 & 12.17 & 31.25 & 74.24 & 45.08 & 32.56 \\
\hline SEm \pm & 0.30 & 0.09 & 0.12 & 0.21 & 0.70 & 0.88 & 0.68 & 0.70 \\
\hline CD at $5 \%$ & NS & 0.27 & 0.34 & 0.61 & NS & 2.55 & 1.96 & NS \\
\hline \multicolumn{9}{|c|}{ Level of sulphur $\left(\mathrm{kg} \mathrm{ha}^{-1}\right)$} \\
\hline $\mathrm{S}_{0}$ & 15.63 & 4.05 & 5.81 & 9.94 & 28.97 & 66.28 & 41.02 & 32.05 \\
\hline $\mathbf{S}_{1}$ & 16.25 & 4.25 & 6.81 & 11.81 & 30.00 & 71.44 & 42.92 & 32.05 \\
\hline $\mathbf{S}_{2}$ & 16.38 & 4.43 & 7.81 & 12.19 & 30.97 & 73.80 & 44.83 & 32.39 \\
\hline SEm \pm & 0.26 & 0.08 & 0.10 & 0.18 & 0.61 & 0.77 & 0.59 & 0.61 \\
\hline CD at $5 \%$ & NS & 0.23 & 0.30 & 0.52 & NS & 2.21 & 1.70 & NS \\
\hline \multicolumn{9}{|l|}{ Interaction } \\
\hline K X S & NS & NS & Sig. & Sig. & NS & Sig & NS & NS \\
\hline $\mathrm{CV}(\%)$ & 6.49 & 7.57 & 6.29 & 6.44 & 8.09 & 4.34 & 5.49 & 7.56 \\
\hline
\end{tabular}

Table.2 Effect of levels of potassium and sulphur on yield of summer groundnut

\begin{tabular}{|c|c|c|}
\hline Treatments & Pod yield $\left(\mathrm{kg} \mathrm{ha}^{-1}\right)$ & Haulm yield $\left(\mathrm{kg} \mathrm{ha}^{-1}\right)$ \\
\hline \multicolumn{3}{|l|}{ Levels of Potassium } \\
\hline $\mathrm{K}_{0}=0 \mathrm{~kg} \mathrm{~K}_{2} \mathrm{O} \mathrm{ha}^{-1}$ & 1731 & 3683 \\
\hline $\mathrm{K}_{1}=25 \mathrm{~kg} \mathrm{~K}_{2} \mathrm{Oha^{-1 }}$ & 1824 & 3952 \\
\hline $\mathrm{K}_{2}=50 \mathrm{~kg} \mathrm{~K}_{2} \mathrm{O} \mathrm{ha}^{-1}$ & 2030 & 4219 \\
\hline $\mathrm{K}_{3}=75 \mathrm{~kg} \mathrm{~K}_{2} \mathrm{O} \mathrm{ha} \mathrm{i}^{-1}$ & 2128 & 4404 \\
\hline $\operatorname{SEm} \pm$ & 44 & 80 \\
\hline CD at $5 \%$ & 126 & 231 \\
\hline \multicolumn{3}{|l|}{ Levels of Sulphur } \\
\hline$S_{0}=0 \mathrm{~kg} \mathrm{~S} \mathrm{ha}^{-1}$ & 1745 & 3704 \\
\hline$S_{1}=20 \mathrm{~kg} \mathrm{Sha}^{-1}$ & 1956 & 4141 \\
\hline$S_{2}=40 \mathrm{~kg} \mathrm{~S} \mathrm{ha}^{-1}$ & 2083 & 4349 \\
\hline $\operatorname{SEm} \pm$ & 38 & 69 \\
\hline CD at $5 \%$ & 109 & 200 \\
\hline \multicolumn{3}{|l|}{ Interaction } \\
\hline$(\mathbf{K} \times \mathbf{S})$ & Sig. & Sig. \\
\hline CV $(\%)$ & 7.82 & 6.82 \\
\hline
\end{tabular}


Table.3 Effect of levels of potassium and sulphur on quality of summer groundnut

\begin{tabular}{|c|c|c|}
\hline Treatment & Oil content (\%) & Protein content (\%) \\
\hline \multicolumn{3}{|l|}{ Levels of Potassium } \\
\hline $\mathrm{K}_{0}=0 \mathrm{~kg} \mathrm{~K}_{2} \mathrm{O} \mathrm{ha} \mathrm{a}^{-1}$ & 41.88 & 26.87 \\
\hline$K_{1}=25 \mathrm{~kg} \mathrm{~K}_{2} \mathrm{Oha}{ }^{-1}$ & 42.66 & 27.09 \\
\hline $\mathrm{K}_{2}=50 \mathrm{~kg} \mathrm{~K}_{2} \mathrm{O} \mathrm{ha}^{-1}$ & 42.87 & 27.42 \\
\hline $\mathrm{K}_{3}=75 \mathrm{~kg} \mathrm{~K}_{2} \mathrm{Oha^{-1 }}$ & 44.04 & 27.65 \\
\hline SEm \pm & 0.56 & 0.12 \\
\hline C.D at $5 \%$ & NS & 0.33 \\
\hline \multicolumn{3}{|l|}{ Levels of Sulphur } \\
\hline$S_{0}=0 \mathrm{~kg} \mathrm{Sha}^{-1}$ & 41.76 & 27.00 \\
\hline$S_{1}=20 \mathrm{~kg} \mathrm{Sha}^{-1}$ & 43.08 & 27.29 \\
\hline$S_{2}=40 \mathrm{~kg} \mathrm{Sha}^{-1}$ & 43.75 & 27.48 \\
\hline SEm \pm & 0.48 & 0.10 \\
\hline CD at $5 \%$ & 1.39 & 0.29 \\
\hline \multicolumn{3}{|l|}{ Interaction } \\
\hline$(\mathbf{K} \times \mathbf{S})$ & NS & NS \\
\hline CV $(\%)$ & 4.50 & 1.47 \\
\hline
\end{tabular}

\section{Effect of sulphur on yield}

Application of sulphur produced significant effect on pod and haulm yields of groundnut (Table 2). Significantly the highest pod yield $\left(2083 \mathrm{~kg} \mathrm{ha}^{-1}\right)$ was noted with application of $40 \mathrm{~kg} \mathrm{~S} \mathrm{ha}{ }^{-1}$ than rest of the treatments. Significantly the highest haulm yield (4349 $\left.\mathrm{kg} \mathrm{ha}^{-1}\right)$ was noticed in treatment $\mathrm{S}_{2}(40 \mathrm{~kg} \mathrm{~S}$ $\left.\mathrm{ha}^{-1}\right)$. Lowest haulm yield $\left(3704 \mathrm{~kg} \mathrm{ha}^{-1}\right)$ was recorded in treatment $S_{0}\left(0 \mathrm{~kg} \mathrm{~S} \mathrm{ha}^{-1}\right)$. These results can be ascribed to effect of sulphur application on cell division, enlargement and elongation resulting in overall improvement in plant organ associated with faster and uniform vegetative growth of the crop.

Potassium in combination with sulphur showed significant effect on yield of groundnut. Combined application of potassium@75 kg ha ${ }^{-1}$ and sulphur @ $40 \mathrm{~kg}$ $\mathrm{ha}^{-1}$ resulted the highest pod yield and haulm yield of groundnut. Significant increase in number of pod yield and haulm yield by interaction of potassium and sulphur might be due to the synergistic effect of potassium and sulphur application in improving yield of plant. This finding is supported by Singh (2007).

\section{Effect of potassium on quality}

Results revealed that effect of various levels of potassium was found to be non-significant in oil content. Application of $75 \mathrm{~kg} \mathrm{~K}_{2} \mathrm{O} \mathrm{ha}{ }^{-1}$ recorded significantly higher protein content (27.65\%), but it was remained at par with the treatment $\mathrm{K}_{2}(27.42 \%)$. Effect of potassium on protein content might be due to the fact that soil under experiment was medium in available potassium so response gets more in $75 \mathrm{~kg} \mathrm{~K} \mathrm{~K}_{2} \mathrm{O} \mathrm{ha}^{-1}$. Potassium promotes the conversion of plant metabolites into proteins and amino acids, thus providing a sink for the nitrogen fixed.

\section{Effect of sulphur on quality}

The application of sulphur increased the oil content and protein content in kernels of 
groundnut significantly (Table 3). Significantly higher oil content $(43.75 \%)$ was noted with treatment $S_{2}\left(40 \mathrm{~kg} \mathrm{~S} \mathrm{ha}{ }^{-1}\right)$ which was at par with treatment $S_{1}(43.08 \%)$.

The treatment $\mathrm{S}_{0}$ (control) recorded the lowest oil content (41.76\%). This results may be attributed to the sulphur plays an important role in synthesis of essential amino acids like cysteine, methionine and certain vitamin like biotin, thymine as well as the formation of ferodoxin (iron containing plant protein) that act as an electron carrier in the photosynthetic process and chlorophyll which required for the production of oil. Treatment receiving application $40 \mathrm{~kg} \quad \mathrm{~S} \mathrm{ha}^{-1}\left(\mathrm{~S}_{2}\right)$ recorded significantly higher protein content $(27.48 \%)$ which was at par with $20 \mathrm{~kg} \mathrm{~S}$ ha $^{-1}\left(\mathrm{~S}_{1}\right)$ $(27.29 \%)$. Whereas lowest protein content $(27.00 \%)$ was recorded under treatment $S_{0}$ (control). Sulphur besides being a structural component of protein is also directly involved in protein bio-synthesis. Interaction effect of potassium and sulphur was found to be nonsignificant in oil content and protein content.

Based on results of one year experiment, it seems quite to conclude that for getting higher yield and quality of summer groundnut under irrigated condition for middle Gujarat Agroclimatic zone; the crop should be fertilized with $50 \mathrm{~kg} \mathrm{~K}_{2} \mathrm{O} \mathrm{ha}^{-1}$ along with $40 \mathrm{~kg} \mathrm{~S}^{-1}$ besides the recommended dose of nitrogen and phosphorus.

\section{References}

A.O.A.C., (1965). The Association of Official Analytical Chemists. $10^{\text {th }}$ Ed. Washington, DC, pp. 744-745.

FAO STAT (2007). FAO Statistics, FAO, Rome, Italy.

Gangadhara, G. A., Manijunathaiah, H. M. and Stayanarayana, T. (1990). Effect of sulphur on yield, oil content of sunflower and uptake of micronutrient by plants. Journal of Indian Society of Soil Science, 38, 693-695.

Gupta, P. C., Miller, D. A. and Hittle, C. N. (1973). Soyabean and quality as influenced by variety and planting date grown at two locations in India. Seed Research, 1, 67-74.

Naiknaware, M. D., Pawar, G. R. and Murumkar, S. B. (2015). Effect of varying levels of boron and sulphur on growth, yield and quality of summer groundnut (Arachis hypogea L.). International Journal of Tropical Agriculture, 33 (2), 471-474.

Sahay, Neha, Singh, S. P. and Sharma, V. K. (2013). Effect of cobalt and potassium application on growth, yield and nutrient uptake in lentil (Lens culinaris L.). Legume Res, 36 (3), 259-262.

Singh, A. L. (1999). Mineral nutrition of groundnut! In: Advances in plant physiology scientific publisher, India, 2, 161-200.

\section{How to cite this article:}

Patel, P.K., M.B. Viradiya, V.H. Kadivala and Shinde, R.D. 2018. Effect of Potassium and Sulphur on Yield Attributes, Yield and Quality of Summer Groundnut (Arachis hypogaea L.) under Middle Gujarat Condition. Int.J.Curr.Microbiol.App.Sci. 7(09): 2268-2273. doi: https://doi.org/10.20546/ijcmas.2018.709.281 